\title{
The Other Side of the Coin: An Exploratory Study of Perception of Instructors' Bullying in University
}

\author{
Ju, Juno ChunLin and Young, TingYuan
}

\begin{abstract}
When we try to put an end to bullying in campus, unintentionally or purposely, the bullying of instructors was passed over. The study intended to explore the relationships among self-assertiveness, school support, organizational commitment and perception of instructors' bullying in undergraduates. In the current study 268 college students was recruited and internet questionnaire was used to collect data. The results showed that above half of the participants $(51.87 \%)$ had experienced instructors bullying, and the verbal bullying was the most common form, relational bullying was followed. As hypothesized, the perception of instructors bullying was negatively related to self-assertiveness, school support, and organizational commitment. The findings suggest that educational organizations can develop self-assertiveness programs to enhance assertive interpersonal interaction skills in both instructors and students. More radically, the school may execute zero-bullying policy.
\end{abstract}

Keywords-Organizational Commitment, Perception of Instructor's Bullying, School Support, Self-Assertiveness

\section{INTRODUCTION}

BULLYING might not uncommon in education facilities. Reference [29] conducted a bullying study targeted the first to ninth-graders in Norway and Sweden. The researchers found $15 \%$ of students had encountered bullying events in the recent five months. Reference [7] surveyed the fifth, seventh to eighth, and tenth to eleventh graders with stratified random sampling in Republic of China (Taiwan) in 2013. It was found that $48 \%$ of male and $52 \%$ female students $(N=4,980)$ had experienced bullying in schools, and prevalence was $30.1 \%$, $36.0 \%$, and $33.9 \%$ in primary, junior high and senior high schools respectively. Therefore, bullying is a worldwide phenomenon.

Bullying can create great impacts and long term influence on victims, witnesses, families, schools, and the society [42], such as adaptation problem, psychological and physical traumas, loss of learning interests and learning effectiveness [6], [37], [38].

Usually bullying is more often in the primary schools and the prevalence gradually decreases when students step into the last year in senior high school [28], [39]. It might due to the older students show self-assertiveness which is an important determinant in bullying [16].

Manuscript received May 7, 2017. This work was supported in part by the Ministry of Science and Technology, R.O.C. under Grant NSC 101-2815-C-130-106-H.

Juno ChunLin Ju is with the Department of Counseling and I/O Psychology, Ming Chuan University, GuiShan, n80; e-mail: doctorjunoju@ yahoo.com).

TingYun Young is with the same affiliation.
Bullying will not limited among students, the instructors might expose bullying nonverbally or verbally, just like the phenomenon in working place [25]. However the related studies are scarce, therefore, the purposes of the research was to understand the prevalence of instructor's bullying, at the same time, explore the relationships among undergraduates' self-assertiveness, school support, organizational commitment and perception of instructor's bullying.

\section{A. Perception of Instructor's Bullying}

Bullying is someone or a group of people with imbalanced power who impose intentional, aggressive and potential to be repeated physical, psychological, and/or verbal aggression, and the bullied person with no way to resist [9], [21], [30], [36].

Reference [30] defined nine types of bullying, other than physical, verbal, relational, counter attack, sexual, and cyber bullying, he suggested bullying through lies and false rumors, having money or other things taken or damaged, threats or being forced to do things, and racial bullying. Most of research found that verbal bullying is the most common form of bullying, even in Taiwan, ROC [20], [44].

Most of bully would deny their violent behaviors, therefore the study target on the perception of bullying.

\section{B. Self-Assertiveness}

Self-assertiveness usually means a positive behavior by which one can properly express one's emotion and opinions in taking care of one's own and others' right and without too much anxiety or worries [23], [24]. At the same time, self-assertiveness will influence one's self-evaluation, which makes oneself feeling sense of importance and value, also improves acceptance of self and self-liking [40].

Reference [2] found that unassertive persons often feel ashamed, unable to maintain their right, and rely on others to make decisions for them. Unassertiveness results in low self-esteem and feeling anxious in unassertive person, while other people might misunderstand and neglect, even incur violence on unassertive person's rights [32].

On the contrary, assertive people would be honest to self and use a way to refuse unreasonable request and yet will not hurt the other party's dignity [16].

Take a step further, self-assertiveness can be the explicit expression of self-confidence, and it is positively related to self-protection effectively [16]. Self-assertiveness can been seen as behaviors which speaks for, defending, and pursuing one's personal interests but not harm the other's side's interest [3]. 


\section{School Support}

The victims who having few social support tend to experience higher frequency and types of bullying. Mush of the past research support this point of view [12], [15], [35].

School support is one form of social support, students in institute acknowledge the care and assistance of administrative systems, instructors, and the peers through school support.

In dealing with bullying in campus, the administrative systems play an important role in it. The school may help students in problem solving, adaptation to the environment, overcoming learning difficulties, and provision of resources in need [21]. Additionally, if the school can establish clear policy about bullying and are responsible for the enforcement, the bullying problem will be under controlled [30].

Reference [10] found that peer support and response will increase the awareness of bullying and buffer the impacts of bullying. At the same time, if the teacher can intervene immediately, appropriately and impartially, the bullying among students would fade away [10], [13].

\section{Organizational Commitment}

Reference [27] developed an organizational commitment questionnaire and proposed three components of organizational commitment, which were identification of organization's goals and values, and a willingness to contribute to and stay in the organization. Organizational commitment is seen as a positive attitude which maintains the organizational competition [26], and contribute to employees' better performance, lower absence, and higher retention [11], [34].

Research found victims of bullying in workplace would impact their commitment to organization, thereafter job performance and satisfaction decreased [4], [14], [22]. Similarly, student victims of bullying in campus will have a falling grade, lack of interesting in study, and might develop school phobia [6], [37].

Accordingly, we hypothesized that:

Hypothesis 1: The more self-assertiveness the undergraduate students have, the less the perception of instructor's bullying they might experience.

Hypothesis 2: The more school support the undergraduate students perceived, the less the perception of instructor's bullying they might experience.

Hypothesis 3: The more perception of instructor's bullying the undergraduate students perceived, the less organizational commitment they might demonstrate.

\section{METHODS}

\section{A. Participants and Procedure}

The study used web questionnaire to collect data from undergraduates in ROC. The questionnaires were completed anonymously and voluntarily. We obtained 268 effective samples, among these participants, $69 \%$ were female, $31 \%$ were male; $19 \%$ were freshman, $22 \%$ were sophomore, $24 \%$ were junior, $33 \%$ were senior, and $2 \%$ were other.

\section{B. Measures}

Self-assertiveness scale was adopted and revised from [5] and [1] to measure participants' degree of self-assertiveness on a 6 -point scale $(1=$ strongly disagree, $6=$ strongly agree $)$. After pilot test, a 24-item scale was developed (Cronbach's $\alpha=.849$ in the current study). Sample items include "I can always express my opinions in group discussion" as well as "It is difficult for me to refuse people's request" (reversed coded). We reversed the scores so that higher scores represent higher assertiveness.

A 10-item scale developed by [43] was used to measure perception of instructor's bullying (Cronbach's $\alpha=.872$ in the present study $)$ on a 5 -point scale $(1=$ strongly disagree, $5=$ strongly agree). We revised the wording to match the bullying between the instructors and students. An example item is "My instructor ridicules me." Higher scores represent more perception of bullying.

School support scale was adopted and revised from [17]. This 10-item scale assesses perception of school support (Cronbach's $\alpha=.834$ in the current study), sample item is "School administrative departments will provide assistance to students in need." Respondents were asked to rate their agreement on a 5 -point scale $(1=$ strongly disagree, $5=$ strongly agree).

A 12-item organizational commitment inventory developed by [8] was used to measure participants' commitment to school (Cronbach's $\alpha=.842$ in the present study). Sample items are "I identify with the mission and prospections of the school," "I strive for outstanding performance in honor of the school," as well as "I appreciate the chance to study in this school." Respondents were asked to rate their agreement on a 5-point scale $(1=$ strongly disagree, $5=$ strongly agree $)$. Higher scores represent better school commitment after we reversed the scores.

\section{FINDINGS}

Almost half, a $48.13 \%(n=129)$ of participants reported no bullying experiences by the instructors (see Figure 1).

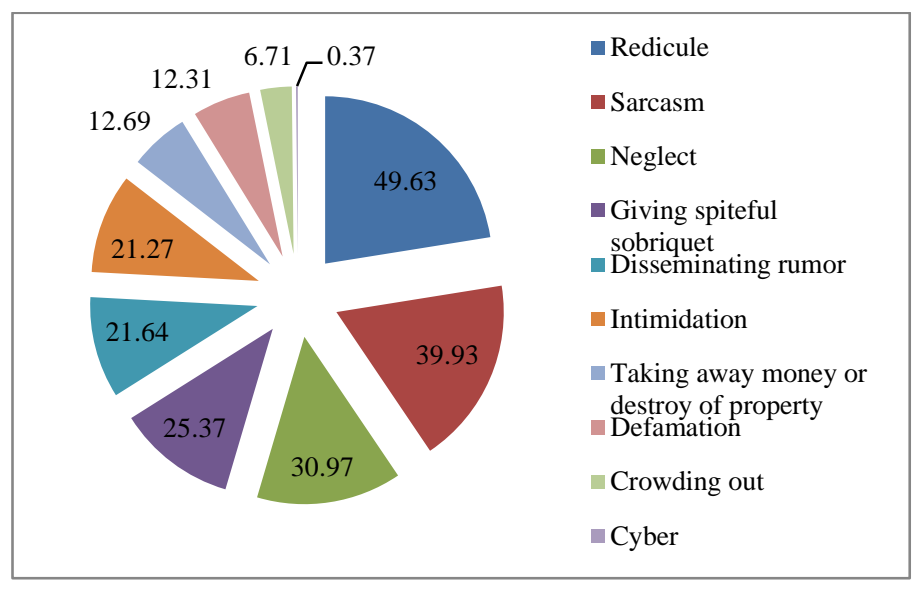

Fig. 1 Frequencies of types of instructor's bullying 
Pearson's correlation showed that self-assertiveness, school support, organizational commitment were negatively related to perception of instructor's bullying $(r=-.29, p=.006 ; r=-.37, p$ $=.008 ; r=-.18, p=.003$ respectively), suggesting that the more self-assertiveness and school support students had, the less perception of instructor's bullying they experienced. In addition, the more perception of instructor's bullying students experienced, the less school commitment they displayed. These results provided support for hypotheses 1, 2 and 3 .

\section{GENERAL DISCUSSION}

The goal of the current study was to explore the unspoken instructor's bullying toward undergraduate students. We believe that it is a double untouchable issue, because of the nature of victim plus underdog making it unnoticeable. The results show over half of the undergraduate participants $(51.87 \%)$ had experienced instructor's bullying while studying in universities. Among these, ridicule is the most often used type of bullying (49.63\%), sarcasm (39.93\%) and neglect $(30.97 \%)$ follows. Generally speaking, a $62.76 \%$ of bullying person/type is expressed verbally among ten forms of bullying. In addition, the results support negative correlations between self-assertive in students and perception of instructor's bullying, school support and bullying, as well as organizational commitment and bullying.

However, some limitations of this study are worth mentioning. The current study is a single-time cross-sectional study, which may lead to some common method bias [33]. We can make it into a longitudinal design to collect more data and reduce the common method variance problem and the possible homogeneity of the sample. Furthermore, power distance might be a moderating variable playing a role in students' perception of instructor's bullying, therefore, the further study can take it into account.

This research makes several contributions to the existing body of literature. First, we shed light on the instructor's bullying toward students. To our knowledge it is the first time the issue has been examined.

Secondly, the current study reminds us the counter-effect of instructor's bullying which might lead to the students losing of commitment to the school.

Third, the current study also provides some guidance for managing instructor's bullying. One way is to boost students' self-assertiveness which may result in personal benefit and the problem subsides. The other way, if the school can increase support toward students in administrative dimension, such as highlight the code of ethics for educators and set up friendly due procedure, it might decrease the prevalence of instructor's bullying. In addition, the school can create ways to make the campus friendly. In this way, we solve the problem not only focusing the individual level, but expanding the efforts in environmental level.

\section{REFERENCES}

[1] Alberti, R. E., \& Emmons, M. L. (1978). Your perfect right: A guide to assertive behavior (3rd ed.). San Luis Obispo, CA: Impact Press.
[2] Alberti, R. E., \& Emmons, M. L. (2001). Your perfect right: Assertiveness and equality in your life and relationships (8th ed.). Atascadero, CA: Impact Publishers.

[3] Ames, D. R. (2008). Assertiveness expectancies: How hard people push depends on the consequences they predict. Journal of Personality and Social Psychology, 95(6), 1541-1557.

[4] Bilgel, N., Aytac, S., \& Bayram, N. (2006). Bullying in Turkish white collars worker. Occupational Medicine, 56, 226-231.

[5] Booraem, C. D., \& Flowers, J. V. (1978). A procedural model for the training of assertive behavior. In J. M. Whiteley \& J. V. Flowers (Eds.), Approaches to assertion training (pp. 15-46). Monterey, CA: Brooks/Cole.

[6] Bradshaw, C. P., O’Brennan, L., \& Sawyer, A. L. (2008). Examining variation in attitudes toward aggressive retaliation and perceptions of safety among bullies, victims, and bully/victims. Professional School Counseling, 12(1), 10-21.

[7] Child Welfare League Foundation. R.O.C. (2014). The 2014 bullying survey in Taiwan campus. Retrieved from http://www.children.org.tw

[8] Chou, C. B. (2007). The study of school organizational culture and teachers' organizational commitment in primary school. School Administration, 49, 84-106.

[9] Clarke, E., \& Kiselica, M. (1997) A systematic counseling approach to the problem of bullying. Elementary School Guidance and Counseling, 31(4), 310-325.

[10] Cross, T. L. (2001). The many faces of bullies. Gifted Child Today Magazine, 24(4), 36-37.

[11] Dee, J. R., Henkin, A. B., \& Singleton, C. A. (2006). Organizational commitment of teachers in urban schools examining the effects of team structures. Urban Education, 41(6), 603-627.

[12] Eliot, M., Cornell, D., Gregory, A., \& Fan, X. (2010). Supportive school climate and student willingness to seek help for bullying and threats of violence. Journal of School Psychology, 48, 533-553.

[13] Gini G. (2006). Bullying as a social process: The role of group membership in students' perception of inter-group aggression at school. Journal of School Psychology, 44, 51-65.

[14] Harris, K. J., Kacmar, K. M., \& Zivnuska, S. (2007). An investigation of abusive supervision as a predictor of performance and the meaning of work as a moderator of the relationship. The Leadership Quarterly, 18, 252-263.

[15] Hazler, R. J. \& Denham, S. A. (2002), Social isolation of youth at risk: Conceptualizations and practical implications. Journal of Counseling Development, 80(4), 403-409.

[16] Henderson, Z. P. (1993). Self-protection programs for children: What works? HumanEcology, 21(3), 27-29.

[17] Ho, H. Y., \& Guo, D. Y. (2012). The relationship between students' perception under school support and bullying behaviors in the junior high school of Tainan city. Journal of Education, 27, 83-131.

[18] Hofstede, G. (1980). Culture's consequences: International differences in work related values. Beverly Hills, CA: Sage.

[19] Hofstede, G. (1991). Cultures and organizations: Software of the mind. Berkshire, UK: McGraw-Hill.

[20] Holben, D. M., \& Zirkel, P. A. (2016). School bullying case law: Frequency and outcomes for school level, protected status, and bullying actions. Ethical Human Psychology \& Psychiatry, 18(2), 111-133.

[21] Hoover, J., \& Hazler, R. J. (1991). Bullies and victims. Elementary School Guidance and Counseling, 25, 212-220.

[22] Johnson, S. L. (2009). International perspectives on workplace bullying among nurses: A review. International Nursing Review, 56(1), 34-40.

[23] Kim, Y. (2001). The effects of assertiveness training on enhancing the social skills of adolescents with visual impairments. Dissertation Abstracts International, A Humanities and Social Sciences, 62(4-A), 13-76.

[24] Landazabal, M. G. (2001). Assessment of a cooperative-creative program of assertive behavior and self-concept. Spanish Journal of Psychology, 2(1), 3-10.

[25] Lin, W. P., Wang, L., \& Chen, S. T. (2013). Abusive supervision and employee well-being: The moderating effect of power distance orientation. Applied Psychology: An International Review, 62(2), 308-329.

[26] Meyer, J. P., Becker, T. E., \& Vandenberghe, C. (2004). Employee commitment andmotivation: A conceptual analysis and integrative model. Journal of Applied Psychology, 89(6), 991-1007.

[27] Mowday, R. T., Steers, R. M., \& Porter, L. W. (1979). The measurement of organizational commitment. Journal of Vocational Behavior, 14, 224-247. 
[28] Nansel, T. R., Overpeck, M., Pilla, R. S., Ruan, W., Simons-Morton, B., $\&$ Scheidt, P. (2001). Aggression behaviors among US youth: Prevalence and association with psychosocial adjustment. Journal of the American Medical Association, 285, 2094-2100.

[29] Olweus, D. (1993). Bullying at school: What we know and what we can do. Oxford: Blackwell.

[30] Olweus, D. (1994). Annotation: Bullying at school: Basic facts and effects of a school based intervention program. Journal of Psychology and Psychiatry, 35(7), 1171-1190.

[31] Olweus, D. (2004). The Olweus bullying prevention programme: Design and implementation issues and a new national initiative in Norway. In P. K. Smith, D. Pepler, \& K. Rigby (Eds.), Bullying in schools: How successful can interventions be? (pp. 13-36). New York: Cambridge University Press.

[32] Paterson, R. J. (2001). The assertiveness workbook: How to express your ideas and stand up for yourself at work and in relationships. Oakland, CA: New Harbinger.

[33] Podsakoff, P. M., MacKenzie, S. B., Lee, J. Y., \& Podsakoff, N. P. (2003). Common method biases in behavioral research: A critical review of the literature and recommended remedies. Journal of Applied Psychology, 88, 879-903.

[34] Reyes, P. (1990). Teachers and their workplace: Commitment, performance, and productivity. Beverly Hills, California: Sage.

[35] Rigby, K. (1996). Bullying in schools: And what to do about it. Bristol, PA: Jessica Kingsley Publishers.

[36] Salmivalli, C., Lagerspetz, K., Bjorkqvist, K., \& Osterman, K. (1996). Bullying as a group process: Participant roles and their relations to social status within the group. Aggressive Behavior, 22(1), 1-15.

[37] Schwartz, D., \& Chang, L. (2001). Correlates of victimization in Chinese children's peer groups. Developmental Psychology, 37, 520-532.

[38] Slee, P. T. (1994). Situational and interpersonal correlates of anxiety associated with peer victimization. Child Psychiatry and Human Development, 25(2), 97-107.

[39] Smith, P. K., Morita, Y., Junger-Tas, J., Olweus, D., Catalano, R., \& Slee, P. (Eds.). (1999). The nature of school bullying. London: Routledge.

[40] Tesser, A., \& Cornell, D. P. (1991). On the confluence of self process. Journal of Experimental Social Psychology, 27, 501-526.

[41] Tyler, T. R., Lind, E. A., \& Huo, Y. J. (2000). Cultural values and authority relations: The psychology of conflict resolution across cultures. Psychology, Public Police, and Law, 6, 1138-1163.

[42] Wei, H. S., \& Huang, C. K. (2005). Reviewing school bullying research: Empirical findings and methodical considerations. NTTU Educational Research Journal, 16(1), 69-112.

[43] Wu, W. Z. (2006). The correlations of fifth and sixth graders' personality, parent-child relationship and the consciousness-response of suffering bullying. Unpublished thesis. ChiaYi, ROC: National ChiaYi University.

[44] Yang, S. C., Lin, C.-Y., \& Chen, A.-S. (2014). A study of Taiwanese teens' traditional and cyberbullying behaviors. Journal of Educational Computing Research, 50(4), 525-552.

Juno C.-L. Ju holds doctoral degree in clinical psychology in USA and am a licensed clinical psychologist and social worker in Republic of China (Taiwan). Currently Dr. Ju serves as Chair of the Department of Counseling and Industrial/Organizational Psychology at Ming Chuan University, GuiShan, TaoYuan, Taiwan, ROC. 